\title{
Dairy industry scrutinizes rBST
}

B efore the advent of recombinant bovine somatotropin ( $\mathrm{rBST}$ ), dairy producers adopted new technologies without much debate. By the time the moratorium on rBST sales was lifted February 4,1994 , that picture had changed.

UC Cooperative Extension Marketing Specialist Leslie "Bees" Butler, who studies adoption and diffusion of new technologies, has tracked the attitudes and opinions of 260 California dairy farmers about rBST since 1987.

"We have seen a significant decline in producers who say they will use rBST and a significant increase in those who say they will not use rBST," Butler said (table 1). Major reasons given are public reaction to $\mathrm{rBST}$ use, possible herd health problems, and the potential economic impact of rBST on milk prices due to consumer rejection and increased production.

However, survey data may not tell the whole story, according to Leon Weaver, Director of the UC Davis Veterinary Medicine Teaching and Research Center in Tulare (VMTRC). "Since the product's release, several producer groups have contacted us," he said. "They want us to talk to their members about whether to use it and how."

Butler said that if subsequent studies reveal a higher than expected rate of adoption, it would indicate that his surveys - conducted prior to rBST release - were not reliable predictors of how people would actually respond. Butler will track rBST use for the next 3 years.

Initially, producers were concerned about rBST effects on milk quality and safety. However, numerous studies indicated that milk from treated cows was safe for humans. Natural BST is a bovine growth hormone normally present in cow's milk, said Donald Klingborg, Director of Veterinary Medicine Extension, UC Davis. The use of the synthetic twin - rBST - does not result in a distinguishable difference in the cow's milk. In the human digestive tract, it is broken down like other proteins, he said.

Trials conducted by VMTRC demonstrated that rBST requires cows to work harder to produce extra milk, which may require additional nutritional support, may reduce pregnancy rates, and may increase risk of mastitis.

\section{Impacts on the farmer}

For the last 30 years, advances in technology and dairy herd management have reduced the number of cows needed to produce the same amount of milk. Since 1970, California's commercial milk production has more than doubled, while the number of cows has increased only $53 \%$. During the same period, production per cow has risen $54 \%$ and 2,000 of 4,473 dairies have gone out of business. The development of rBST may accelerate this trend, according to a 1991 report by the Office of Technology Assessment.

Studies indicate that cows receiving $\mathrm{rBST}$ can increase milk production 10 to $15 \%$. That would increase net income per treated cow $\$ 100$ to $\$ 150$ annually, if milk prices remain constant. Regardless of herd size, any dairy adopting rBST can ben-

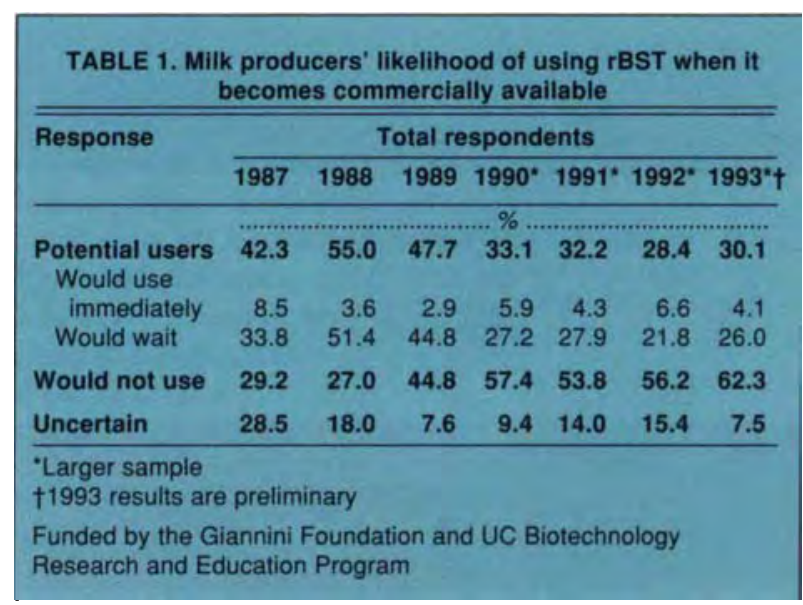
efit, but results will vary based on herd management.

A major issue is the aggregate effects of increased milk production, Butler said. If production rises and demand remains constant, prices typically fall. Less efficient dairies are more vulnerable to a narrowing profit margin.

"Increases in aggregate milk production as small as $2 \%$ per year can have large impact on the prices paid for milk and dairy commodities," Butler said. "Price supports keep prices from falling below the current $\$ 10.10$ per hundredweight of milk. However, increases in federal program purchases beyond 7 billion pounds milk equivalent will result in an assessment on all dairy producers - whether they use rBST or not."

\section{Impacts on society}

In a January 1994 report, the Office of Management and Budget (OMB) projected that rBST use would increase U.S. milk production $1 \%$ through 1999. Assuming this, OMB estimates that resulting price-support costs would go up about $\$ 150$ million 


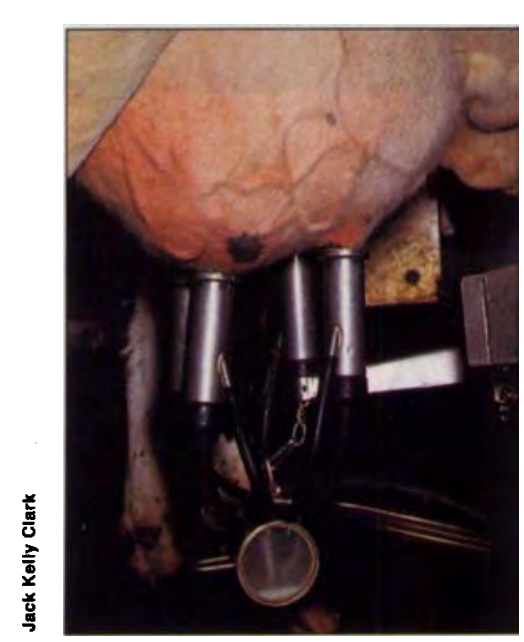

in 1996, the peak year, and decline in later years. However, these costs could be offset by savings to federal nutrition programs.

Opponents question the animal health, environmental and socio-economic implications of rBST use. The Sustainable Agriculture Research and Education Program (SAREP) cautions rural communities may suffer if dairies go out of business. SAREP's book The Dairy Debate claims that cows receiving rBST would need to eat more grain, therefore increasing feed grain acreage on which pesticides are used.

Weaver disagreed. "As milk production goes up, fewer cows are needed. Fewer cows make less manure and eat less total feed, which reduces the acreage used to produce the feed."

\section{Mastitis, antibiotic use}

Researchers have noted that more productive cows seem to experience a higher incidence of mastitis, an udder infection treated with antibiotics. Klingborg explained the risk of mastitis can be mitigated through sanitation. However, some people fear higher risk of mastitis will lead to more antibiotics, posing a risk to human health, according to Jill
Auburn, Associate Director of SAREP.

Klingborg said, "Currently, every tanker truck of milk is screened at the creamery using extremely sensitive tests for specific antibiotics. Random testing is done for a wide variety of other antibiotics."

Dairies also face economic deterrents to providing milk containing antibiotic residues. "The dairyman not only loses the day's milk, he has to pay for all the milk in the truck or milk plant that his milk contaminated," Weaver explained "It could range from $\$ 6,000$ to $\$ 50,000$." In addition to financial penalties, if a dairy is cited three times it may lose its right to sell milk.

Implementation of the testing program, regulations and economic penalties have diminished use of drugs at dairies, according to Weaver. "There are fewer drugs used; in particular, exotic drug use has declined," he said.

-Editor

\section{Further reading:}

"Safety of Bovine Somatotropin in Dairy Cows: Results and Recommendations," by Osburn, Holmberg and Weaver, the School of Veterinary Medicine at UC Davis. The Dairy Debate: Consequences of bovine growth hormone and rotational grazing technologies, recently published by the UC statewide SAREP program; Maintaining the Competitive Edge in California's Dairy Industry, Part II by L. J. Butler.

\section{(1)}

\section{Mystery disease spotted in vineyards}

Several young vineyards in Napa and Sonoma counties have been ailing from a disease that has thus far stumped viticulturists.

Typical leaf symptoms include a

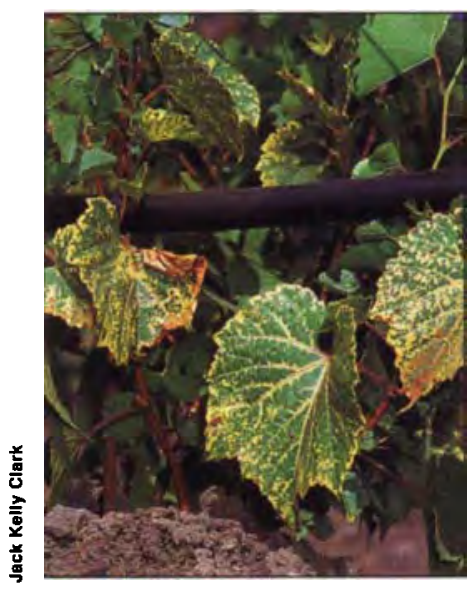

Have you seen these symptoms? wide range of patterns of veinal and interveinal chlorosis. In some cases, the leaves lose their green coloring and appear bleached. Marginal burning, usually in sections of the leaf, often accompanies the chlorosis. Shoot growth stops prematurely and the vines are usually stunted.

Having ruled out herbicide injury and common viruses as causes, Napa County Farm Advisor Ed Weber is planning to conduct trials this spring. According to Weber, a lack of mycorrhizal fungi in fumigated soil may be the root of the problem. These fungi play an important role in the uptake of micronutrients in grapevines' root sys- tems, so he theorizes an unusual nutrient deficiency may be causing the disease.

"We will be innoculating mycorrhizae into symptomatic vineyards and to new vineyards planted this spring," Weber said.

\section{Barley engineered}

UC Berkeley plant biologists Peggy Lemaux and Yuechun Wan have introduced viral genes into barley to help the plant resist barley yellow dwarf virus. The virus, ranked among the most problematic barley diseases, weakens plants and lowers crop yields.

The researchers published the first article describing the successful barley gene insertion technique, which they developed at the Plant Gene Expression Center in Albany, in the January issue of Plant Physiology.

Federal permits have been issued for field tests to be held this summer in California, Idaho and Illinois. 